\title{
The Art of Xenofon Kavvadias
}

\author{
Shakila Maan
}

In April 2011, Xenofon Kavvadias mounted an exhibition entitled The law is no less conceptual than fine art, based on the words of Lord Carlile of Berriew who provided legal advice after the Metropolitan police had warned Kavvadias that he could be arrested and prosecuted under the Terrorism Act 2006 if he mounted any exhibition that featured texts such as The Islamic Ruling on the Permissibility of Martyrdom Operations, a justification for suicide bombings used by Chechen extremists.

The collection of images used in this Special Issue of Feminist Dissent goes some way in presenting Kavvadias' brilliant exhibition exploring, as he says, the 'limits of acceptability and the margins of legality' within counter terrorism. We feature three streams of the exhibition. The first thread, accompanying the longer journal articles, is a series of close ups of an image entitled Holocauston (not holocaust). The shorter pieces that alternate with the longer articles are accompanied by a series of oil

(C) Copyright: The Authors. This article is issued under the terms of the Creative Commons Attribution Non-Commercial Share Alike License, which permits use and redistribution of the work provided that the original author and source are credited, the work is not used for commercial purposes and that any derivative works are made available under the same license terms. paintings and photographic stills. One of the oil paintings has the title 'And we put him against the wall. A mother's son, a man like we had been and shot him dead. And then to show you all; what came of him we photographed the scene'. Another one has the title: 'It is he who flies above your city. Woman now trembling for your children. From up here we've fixed our sights on you and them as targets. If you ask why, the answer is from fear'. Epigrams 12, 15 and 16, are from the book War Primer by Bertolt Brecht. It is part of the work On War Primer (2014). This painting has been inspired by photographs that depict British war crimes and state terrorism in the last 100 years. Image no 12 has the title: 'Gang Law is something I 
can understand. With man-eaters I've excellent relations. I've had the killers feeding from my hand. I am the man to save the civilisation'.

This short write up of Kavvadias' work is based on the press release issued ahead of his exhibition at Gift in 2011 and an article that he subsequently wrote for Statewatch. We are also pleased to showcase a short clip where Geoffrey Robertson QC speaks at Kavvadias' Private Reception.

The exhibition revolved around images depicting Murano Veronese vases books on display were burnt and ashes placed in these handmade vases, which were inspired by Paolo Caliari's painting The Annunciation (c.1555). Caliari was accused of blasphemy and tried by the Inquisition during which time he said 'sometimes painters take liberties like poets or madmen'. In 1573 Caliari (known as Veronese after this exhibition) completed his controversial work Feast in the House of Levi. Originally the work was painted to depict the Last Supper, but the painting was not approved of by the agents of the Inquisition so Veronese was forced to change its title. The urn's quality and elegance make it the perfect vehicle for Kavvadias' Catharsis and the ideal ultimate symbol for the concepts and motives behind this provoking installation.

Kavvadias says that his 'work deals with the limits of acceptability and the margins of legality, within the law, as an art and research project. I try to realise what can be seen, said or thought under contemporary legislation and situation. I am also interested in investigating the future of these books - could they exist outside an art project, or do they have to be destroyed?'

This exhibition was not centred on issues of faith, religion or party political debate, rather it was concerned with the exposing and questioning of what and why certain information is withheld from access and indeed may be deemed illegal to own, read or exhibit. Where are these lines drawn and who decides? Indeed should they be drawn at all? For, will they not change 
over time? One of the first books to be sensationally banned in several countries and defended in court by Penguin Books was D.H. Lawrence's (1928) Lady Chatterley's Lover due to its explicit content (2 'fucks' and 12 'cunts') and the then socially unacceptable depiction of a relationship between an aristocratic woman and a working-class man. Would it have the same reaction if it were first published now?

To this end, Kavvadias had selected documents from a wide spectrum of contentious and opposing social, political and religious ideologies in order to provide an impartial and balanced viewpoint. During the course of the show, the most contentious books were ceremoniously burned, each week, with the resultant ashes placed within handmade Murano 'Veronese' vases. The charred skeletons of the books void of their contents returned to their original place on the gallery walls.

Far from wishing to expose information that may put lives and/or liberty at risk, Kavvadias and Gift 10 VYNER ST aimed to create a space of freedom and equality where visitors encountered, without any didactic attitude or fear, part of what has been denied to them during the last decades due to terrorism and war. Additional installations incorporating both old and new media also offered challenging perspectives of Kavvadias' oeuvre. 'I believe that in the country where the Magna Carta was signed and John Milton (1644) delivered the Aeropagitica, it is not impossible to differentiate between those who are against the values of 800 years of democratic tradition from those who cherish and believe in them. It is this strong belief that forces one to move outside of the comfort zone in order to defend these values and attempt to reclaim valuable ground that has been lost in a long standing war that the people of this country never really wanted to begin with.'

Kavvadias is interested in exploring the legislation, challenging contemporary notions of freedom of speech, censorship and accepted 
public knowledge thereof. Following more than five years of extensive research and planning, he presents a wide range of documents and books containing disturbing contemporary ideologies. Many of these have been used as evidence in court to secure criminal convictions. Subjected to the obscurities of underground internet websites, the public is essentially exempt from what should be an on-going debate, intimidating an informed electorate and seriously undermining our democratic political state. This exhibition encouraged viewers to critically engage with the displayed texts without fear of control or marginalisation, reinstating the public right to challenge and oppose.

Kavvadias asks 'are thousands of UK households who possess these books breaking the counter-terrorism law? Should they not be informed about it? Should they not be required to destroy the books? Is this a solution within the spirit of the Law? For if we ban a book, how far are we from forcing the owner to destroy it? For if we ask, or force the owner of a book to destroy it, how far are we from burning this book? I am convinced that in this country only a tiny minority is prepared to burn books. The last book I can recall being burned was a copy of Salman Rushdie's (1988) Satanic Verses in Bradford.'

Focusing mainly on literature and texts, Kavvadias presented CIA files and confidential manuals alongside Islamist books and other texts that one may claim 'glorify terrorism in the strict meaning of the word'.

Kavvadias states that 'I am particularly interested in sections 57 and 58 of the TA. In these sections it is stated that; "a person commits an offence if he collects or makes a record of information of a kind likely to be useful to a person committing or preparing an act of terrorism". I am also interested in the 2006 Act where it is stated that; "a person commits an offence if he publishes a statement in which he glorifies terrorism or is likely to be understood by members of the public as direct or indirect encouragement 
or other inducement to the commission preparation or instigation of such acts or causes another to publish such a statement.'

Shakila Maan is an independent film maker and fine artist. A collection of her banners from 1984 to 2018 depicting SBS campaigns have been produced as cards to mark 40 years of Southall Black Sisters. Shakila is a long standing member of Southall Black Sisters and was part of Women Against Fundamentalism.

\section{References}

Kavvadias, X. (2011) The law is no less conceptual than fine art: Exhibition of Illegal Books. Showcased at Gift 10 Vyner Street London E8 between 5th May - 17th June 2011.

Xenofon Kavvadias: International Press Release, April 2011. Available at: http://www.statewatch.org/news/2011/apr/uk-ct-art-exhibitiion.pdf

To cite this article:

Maan, S. (2019) The Art of Xenofon Kavvadias. Feminist Dissent, 4, pp. 274-

278. Retrieved from: https://doi.org/10.31273/fd.n4.2019.413 